\title{
Evaluation of the Impact of Bacillus thuringiensis Serovar israelensis and Temephos, Used for the Control of Simulium (Chirostilbia) pertinax Kollar, 1832 (Diptera, Simuliidae) on the Associated Entomofauna, Paraty, State of Rio de Janeiro, Brazil
}

\author{
Carlos José Pereira da Cunha de Araújo-Coutinho/ ${ }^{+}$, Andrea de Barros Pinto Viviani \\ Cunha, Nicolau Maués Serra-Freire*, Rubens Pinto de Mello**
}

Superintendência de Controle de Endemias, Rua Paula Souza 166, 01027-000 São Paulo, SP, Brasil *Laboratório de Ixodides

**Laboratório de Dípteros, Departamento de Entomologia, Instituto Oswaldo Cruz-Fiocruz, Rio de Janeiro, RJ, Brasil

The study was set up to evaluate the impact of two commercial larvicide formulations, Bacillus thuringiensis serovar israelensis base (Bti) at $15 \mathrm{ppm} / 1 \mathrm{~min}$ and temephos at $0.03 \mathrm{ppm}$ of active ingredient, used to control Simulium pertinax populations, on associated non-target entomofauna occupying the same breeding sites.

The experiments were carried out on the Pedra Branca and Muricana rivers, on the slopes of Serra do Mar massif, municipality of Paraty, state of Rio de Janeiro, Brazil. Bti was applied to the river Pedra Branca and temephos to the river Muricana. On both rivers, treatment and control sections were labeled as such, each one with two observation posts: slow moving water and fast water regions respectively.

Artificial substrata was used to evaluate the abundance of associated entomofauna. Attached immature stages of arthropods were removed from both of its surfaces fortnightly. Were collected, from the two rivers, 28477 specimens of the entomofauna associated with S. pertinax. The families Hydropsychidae, Chironomidae, Bactidae, Simuliidae, Blephariceridae and Megapodagrionidae were represented.

These was an impact of temephos on the entomofauna associated with S. pertinax only in Simuliidae and Chironomidae, and to Bti only in Simuliidae. However, the reduction in their numbers was not statistically significant.

Key words: blackfly control - Simulium pertinax - Bacillus thuringiensis serovar israelensis - temephos

The main program for the control of Simuliidae in Brazil is being conducted on the northern coast of the state of São Paulo, near the slopes of the Serra do Mar massif. The municipalities of this region rely basically on the tourist industry as their source of income (Araújo-Coutinho \& Lacey 1990). Initiated in 1957, and in operation without interruption until now, this program encompasses 1456 simuliid breeding places distributed over an area of 893 $\mathrm{km}^{2}$ (Araújo-Coutinho 1995a).

Resistance of Simulium pertinax to temephos has been known since the 1980's (Ruas Neto 1984). As this is the most important simuliid species in the coastal areas of the states of Rio de Janeiro and São Paulo (Araújo-Coutinho et al. 1988, Maia-Herzog et al. 1988), the program for its control switched to the exclusive use of Bacillus thuringiensis serovar israelensis (Bti) formulations in littoral São Paulo (Araújo-Coutinho 1995b).

Even though the routine use of Bti in the state of São Paulo has satisfactorily kept $S$. pertinax populations

\footnotetext{
${ }^{+}$Corresponding author current address: Laboratório de Simulídeos e Oncocercose, Departamento de Entomologia, Instituto Oswaldo Cruz-Fiocruz, Av. Brasil 4365, 21045-900 Rio de Janeiro, RJ, Brasil. Fax: +55-21-2573.4468. E-mail coutinho@ioc.fiocruz.br

Recevied 11 September 2002

Accepted 11 June 2003
}

within tolerable limits, further study became necessary to evaluate the impact of more than a decade of uninterrupted use of Bti on non-target organisms occurring in simuliid breeding sites. Such information is essential for cost-benefit analysis in connection with the program.

This investigation aims to evaluate and compare the impact, on non-target associated entomofauna occurring in S. pertinax breeding sites, of commercial larvicide formulations with Bti and temephos, respectively, used for the control of Simuliidae.

The choice for those agents' is justified because they are the most efficient larvicides in programs of simuliids control (Andrade \& Castelo Branco Jr. 1990), and although there are some information about the resistance of $S$. pertinax to temephos in certain areas, it continues to be efficient in other areas (Kurtak et al. 1987). The knowledge of the those agents' impact in non-target organisms will be very important in programs of integrated control of simuliids, because the impact is one of the main factors in the cost/benefit analysis.

\section{MATERIALS AND METHODS}

The investigation was carried out from February 1995 to January 1997 in the municipality of Paraty, state of Rio de Janeiro, along the slopes of the Serra do Mar massif (latitude $23^{\circ} 13^{\prime} \mathrm{S}$, longitude $44^{\circ} 45^{\prime} \mathrm{N}$ ). The rivers Pedra Branca and Muricana, the latter a tributary of the former, were selected for the study. In both rivers, cascades, flowing over rocks, and slow moving waters flowing over a stratum of sand, are found. According to the classifica- 
tion by Anderson and Dicke (1960), they are "young streams".

To the river Pedra Branca, a commercial formulation of Bti was applied fortnightly at the concentration of $15 \mathrm{ppm} /$ $1 \mathrm{~min}$. This concentration is used in the program for the control of Simuliidae on the northern coastal region of the state of São Paulo (Araújo-Coutinho 1995b).

To the river Muricana, an emulsifiable temephos formulation, at the concentration of $0.03 \mathrm{ppm}$ of active ingredient for $5 \mathrm{~min}$, was also applied fortnightly. This concentration has been used during the 1970's in the program for the control of simuliidae on the northern coastal region of the state of São Paulo (Sucen 1977).

Both breeding sites were divided into two sections: control, upstream from the larvicide application points; treated, downstream from such points. Two sampling sites each treatment and control zone were marked out: slow water and cascade respectively. Both were sampled fortnightly. To collect associated entomofauna, six artificial substrata (fiberglass plates, 0.33 by $0.22 \mathrm{~m}$ each, with an internal lead ballast to prevent their dislodgement) had been placed as a chain, from one to the other margin of the river, into each sampling site 30 days previously. These artificial substrata are modified, more durable versions of the ceramic ones recommended by Lewis and Bennett (1974).

From both surfaces of the substrata, larval stages of entomofauna attached to them were removed and preserved in $70 \%$ ethanol, labeled with date and site of collection, and sent to the laboratory for identification and counting.

Monthly abundance (specimens $/ \mathrm{m}^{2}$ ) was recorded to estimate population density of the entomofauna at each sampling site, grouped by families, with the exception of $S$. pertinax, the target species of the control activities.

From $10 \mathrm{AM}$ to $11 \mathrm{AM}$ of the same day of the collection of biotic material, the following abiotic data were collected: air temperature $\left({ }^{\circ} \mathrm{C}\right)$, relative humidity $(\%)$, water speed $(\mathrm{m} / \mathrm{s})$, river flow $\left(\mathrm{m}^{3} / \mathrm{min}\right)$, depth of the breeding site at the sampling site $(\mathrm{m}), \mathrm{pH}$, water temperature, dissolved oxygen ( $\mathrm{mg} / \mathrm{l})$, concentration of ammonia $(\%)$ and biological demand for oxygen $(\mathrm{mg} / \mathrm{l})$.

Rainfall data $(\mathrm{mm})$ were obtained from the Meteorological Office of the Center for Agricultural Research, State University of Campinas, São Paulo.
"Student's $t$ " test for paired data (difference between two means) was applied to evaluate differences between the means of abiotic data. The same test was applied to evaluate the significance of differences in abundance of entomofauna in both treated and control sections on each river.

\section{RESULTS}

Abiotic data of the region under study: air temperature $\left({ }^{\circ} \mathrm{C}\right)$ - During the period of the study, the mean temperature was $24.93^{\circ} \mathrm{C}\left(\mathrm{sd}=2.25^{\circ} \mathrm{C}\right)$. The maximum temperature was recorded $\left(40^{\circ} \mathrm{C}\right)$ in November 1995 and the minimum $\left(12^{\circ} \mathrm{C}\right)$ in July 1996 . Relative humidity (\%) - During all the period of study, high levels of humidity were observed, with a mean of $89.89 \%(\mathrm{sd}=4.53 \%)$. The maximum $96 \%$, was recorded in August 1996 and the minimum $81 \%$, in August 1995.

The above-mentioned data pertained to the whole region; climatic oscillations within the short distance separating the rivers under study would not be detected by the instruments used.

Abiotic data recorded from breeding places (Table I) - Data records refer to measurements by the river section. In view of the short distance between sections, oscillations in the chemical composition of the water would not be detected, given the instruments used. As there are no branches flowing in or out of the rivers between the observation sites, measuring flow only within sections is viable.

No significant differences $(5 \%)$ were observed in chemical composition when rivers or sections were compared. Concerning the physical aspect of flow, a considerable difference was observed between the rivers, which had already been expected, as the river Pedra Branca is much larger than the river Muricana.

Abiotic data recorded within the sampling sites (Table II) - Data pairs from each river were analyzed: control cascade section (CC), compared to treated cascade section (TC) and control slow water section (CS) compared to treated slow water section (TS). No significant differences were found (5\%) between the data pairs compared.

Entomofauna - From the control section of the Muricana river, 11624 specimens were collected, 8758 (75.34\%) of which belonged to the species S. pertinax. The remaining 2866 specimens $(24.66 \%$ ) were distributed

TABLE I

Means of abioctic data in control and treated section of Muricana and Pedra Branca rivers, during 1995 to 1997, in rivers Muricana and Pedra Branca, Paraty, state of Rio de Janeiro, Brazil

\begin{tabular}{|c|c|c|c|c|c|c|c|c|}
\hline \multirow{2}{*}{$\begin{array}{l}\text { Abiotic } \\
\text { data }\end{array}$} & \multicolumn{4}{|c|}{ Control section } & \multicolumn{4}{|c|}{ Treated section } \\
\hline & $\begin{array}{l}\text { Discharge } \\
\left(\mathrm{m}^{3} / \mathrm{min}\right)\end{array}$ & $\begin{array}{c}\text { Concentration } \\
\text { of amonia } \\
(\%)\end{array}$ & $\begin{array}{c}\text { Biological } \\
\text { demand for } \\
\text { oxygen (mg/l) }\end{array}$ & $\begin{array}{l}\text { Dissolved } \\
\text { oxygen } \\
(\mathrm{mg} / \mathrm{l})\end{array}$ & $\begin{array}{l}\text { Discharge } \\
\left(\mathrm{m}^{3} / \mathrm{mim}\right)\end{array}$ & $\begin{array}{c}\text { Concentration } \\
\text { of amonia } \\
(\%)\end{array}$ & $\begin{array}{c}\text { Biological } \\
\text { demand for } \\
\text { oxygen (mg/l) }\end{array}$ & $\begin{array}{c}\text { Dissolved } \\
\text { oxygen } \\
(\mathrm{mg} / \mathrm{l})\end{array}$ \\
\hline Rio Muricana & $\begin{array}{c}12.68 \\
(\mathrm{~s}=3.43)\end{array}$ & $\begin{array}{c}1.10 \\
(\mathrm{~s}=0.46)\end{array}$ & $\begin{array}{c}1.76 \\
(\mathrm{~s}=0.54)\end{array}$ & $\begin{array}{c}11.46 \\
(\mathrm{~s}=1.39)\end{array}$ & $\begin{array}{c}10.68 \\
(\mathrm{~s}=4.01)\end{array}$ & $\begin{array}{c}1.08 \\
(\mathrm{~s}=0.69)\end{array}$ & $\begin{array}{c}1.78 \\
(\mathrm{~s}=0.71)\end{array}$ & $\begin{array}{c}11.32 \\
(\mathrm{~s}=1.44)\end{array}$ \\
\hline Rio Pedra Branca & $\begin{array}{c}119.10 \\
(\mathrm{~s}=63.50)\end{array}$ & $\begin{array}{c}1.08 \\
(\mathrm{~s}=0.67)\end{array}$ & $\begin{array}{c}1.69 \\
(\mathrm{~s}=0.59)\end{array}$ & $\begin{array}{c}11.93 \\
(\mathrm{~s}=1.42)\end{array}$ & $\begin{array}{c}111.94 \\
(\mathrm{~s}=63.00)\end{array}$ & $\begin{array}{c}1.08 \\
(\mathrm{~s}=0.63)\end{array}$ & $\begin{array}{c}1.68 \\
(\mathrm{~s}=0.41)\end{array}$ & $\begin{array}{c}11.70 \\
(\mathrm{~s}=1.35)\end{array}$ \\
\hline
\end{tabular}


into six families (Table III), of which Hydropsychidae (1 681 specimens, $58.65 \%$ ), and Megapodagrionidae (one specimen, $0.03 \%$ ) were the most and least prevalent respectively.

From the treated section of the river Muricana, 5675 specimens were collected, $4648(81.90 \%)$ of which belonged to the associated entomofauna (Table III). Hydropsychidae (3 679 specimens, 79.15\%), and Megapodagrionidae ( 20 specimens, $0.43 \%$ ) were the most and least prevalent respectively. For the species S. pertinax, 1027 specimens (18.7\% of the total) were collected.

Concerning S. pertinax (Table IV), CC/TC and CS/TS ratios indicated important reduction in mean abundance: $86 \%$ in the TC and $80.77 \%$ in the TS sampling sites. Only the first was found significant (CC/TC: $t=4.99 ; \mathrm{p}<0.05$ and CS/TS: $t=1.01: \mathrm{P}>0.05)$.

Concerning the family Simuliidae (Table IV), TC and TS sampling sites showed a reduction in mean abundance when compared to $\mathrm{CC}$ and $\mathrm{CS}$ respectively. Although an evident reduction (75.22\%) was observed in TC and a modest one $(13.33 \%)$ in TS, neither was statistically signifi$\operatorname{cant}(\mathrm{CC} / \mathrm{TC}: t=1.90 ; \mathrm{P}>0.05 \mathrm{e} \mathrm{CS} / \mathrm{TS}: t=0.14 ; \mathrm{P}>0.05)$.
Concerning the family Chironomidae (Table IV), the observation post TS showed a moderate reduction in mean abundance $(30.90 \%)$ relatively to CS, but this was not statistically significant $(t=0.85 ; \mathrm{P}>0.05)$. The ratio $\mathrm{CC} /$ $\mathrm{TC}$, the high percentage of reduction notwithstanding $(57.26 \%)$, was not statistically significant $(t=1.13 ; \mathrm{P}>$ $0.05)$.

Concerning the families Bactidae, Blephariceridae, Megapodagrionidae and Hydropsychidae (Table IV), no decrease in population was observed when control and treated sections of both rivers were compared.

From the river Pedra Branca control section, 22119 specimens were collected, 13479 (60.94\%) were S. pertinax and 8640 (39.06\%) were associated entomofauna (Table III). Of this group, the most and the least prevalent families were Hydropsychidae (6 410 specimens, 74.19\%) and Megapodagrionidae (two specimens, $0.02 \%$ ).

From the treated section of the river Pedra Branca 13 831 specimens were collected, of which $1718(12.42 \%)$ of S. pertinax and $12113(87.58 \%)$ of the associated entomofauna (Table III), 6939 (57.29\%) of them belonging to the family Hydropsychidae, the most abundant, while

TABLE II

Means of abiotic data in each point and section of of Muricana and Pedra Branca rivers, during 1995 to 1997, in rivers Muricana and Pedra Branca, Paraty, state of Rio de Janeiro, Brazil

\begin{tabular}{|c|c|c|c|c|c|c|c|c|}
\hline $\begin{array}{l}\text { Observation } \\
\text { points for } \\
\text { section }\end{array}$ & $\begin{array}{l}\text { Contro } \\
\text { of } \mathrm{M}\end{array}$ & $\begin{array}{l}\text { ction } \\
\text { ana }\end{array}$ & $\begin{array}{l}\text { Treate } \\
\text { of } \mathrm{M}\end{array}$ & $\begin{array}{l}\text { ction } \\
\text { ana }\end{array}$ & $\begin{array}{l}\text { Contro } \\
\text { of Ped }\end{array}$ & $\begin{array}{l}\text { ction } \\
\text { ranca }\end{array}$ & $\begin{array}{l}\text { Treat } \\
\text { of Pe }\end{array}$ & $\begin{array}{l}\text { ection } \\
\text { Branca }\end{array}$ \\
\hline Abiotic & Point & Point & Point & Point & Point & Point & Point & Point \\
\hline data & $\mathrm{CC}$ & $\mathrm{CS}$ & $\mathrm{TC}$ & TS & $\mathrm{CC}$ & $\mathrm{CS}$ & $\mathrm{TC}$ & $\mathrm{TS}$ \\
\hline $\begin{array}{l}\text { Depth of } \\
\text { breeding site }(\mathrm{m})\end{array}$ & $\begin{array}{c}0.26 \\
\mathrm{~s}=0.09\end{array}$ & $\begin{array}{c}0.69 \\
\mathrm{~s}=0.07\end{array}$ & $\begin{array}{c}0.26 \\
\mathrm{~s}=0.08\end{array}$ & $\begin{array}{c}0.43 \\
\mathrm{~s}=0.11\end{array}$ & $\begin{array}{c}0.34 \\
\mathrm{~s}=0.12\end{array}$ & $\begin{array}{c}0.93 \\
\mathrm{~s}=0.23\end{array}$ & $\begin{array}{c}0.35 \\
\mathrm{~s}=0.10\end{array}$ & $\begin{array}{c}0.63 \\
\mathrm{~s}=0.10\end{array}$ \\
\hline $\begin{array}{l}\text { Water } \\
\text { temperature }\left({ }^{\circ} \mathrm{C}\right)\end{array}$ & $\begin{array}{c}20.81 \\
\mathrm{~s}=1.98\end{array}$ & $\begin{array}{c}20.99 \\
\mathrm{~s}=2.09\end{array}$ & $\begin{array}{c}20.83 \\
\mathrm{~s}=1.97\end{array}$ & $\begin{array}{c}20.84 \\
\mathrm{~s}=2.00\end{array}$ & $\begin{array}{c}20.53 \\
\mathrm{~s}=2.21\end{array}$ & $\begin{array}{c}20.48 \\
\mathrm{~s}=2.10\end{array}$ & $\begin{array}{c}20.33 \\
\mathrm{~s}=1.98\end{array}$ & $\begin{array}{c}20.37 \\
\mathrm{~s}=2.02\end{array}$ \\
\hline $\mathrm{pH}$ & $\begin{array}{c}7.64 \\
s=0.46\end{array}$ & $\begin{array}{c}7.66 \\
s=0.45\end{array}$ & $\begin{array}{c}7.57 \\
\mathrm{~s}=0.47\end{array}$ & $\begin{array}{c}7.57 \\
\mathrm{~s}=0.44\end{array}$ & $\begin{array}{c}7.71 \\
\mathrm{~s}=0.37\end{array}$ & $\begin{array}{c}7.73 \\
\mathrm{~s}=0.40\end{array}$ & $\begin{array}{c}7.75 \\
\mathrm{~s}=0.46\end{array}$ & $\begin{array}{c}7.80 \\
\mathrm{~s}=0.43\end{array}$ \\
\hline $\begin{array}{l}\text { Water speed } \\
(\mathrm{m} / \mathrm{s})\end{array}$ & $\begin{array}{c}0.87 \\
\mathrm{~s}=0.33\end{array}$ & $\begin{array}{c}0.28 \\
\mathrm{~s}=0.05\end{array}$ & $\begin{array}{c}0.87 \\
\mathrm{~s}=0.33\end{array}$ & $\begin{array}{c}0.28 \\
\mathrm{~s}=0.05\end{array}$ & $\begin{array}{c}0.59 \\
\mathrm{~s}=0.25\end{array}$ & $\begin{array}{c}0.24 \\
\mathrm{~s}=0.12\end{array}$ & $\begin{array}{c}0.57 \\
\mathrm{~s}=0.24\end{array}$ & $\begin{array}{c}0.21 \\
\mathrm{~s}=0.11\end{array}$ \\
\hline
\end{tabular}

CC: control cascade; $\mathrm{CS}$ : control still; TC: treated cascade; TS: treated still

TABLE III

Simulium pertinax associated entomofauna, collected in control and treated section, during 1995 to 1997, in rivers Muricana and Pedra Branca, Paraty, state of Rio de Janeiro, Brazil

\begin{tabular}{|c|c|c|c|c|c|c|c|c|}
\hline \multirow{2}{*}{$\begin{array}{l}\text { River and } \\
\text { Section }\end{array}$} & \multicolumn{2}{|c|}{$\begin{array}{l}\text { Control section of } \\
\text { Muricna }\end{array}$} & \multicolumn{2}{|c|}{$\begin{array}{l}\text { Treated section of } \\
\text { Muricana }\end{array}$} & \multicolumn{2}{|c|}{$\begin{array}{l}\text { Control section of } \\
\text { Pedra Branca }\end{array}$} & \multicolumn{2}{|c|}{$\begin{array}{l}\text { Treated section of } \\
\text { Pedra Branca }\end{array}$} \\
\hline & $\begin{array}{l}\mathrm{Nr} \text { of collected } \\
\text { specimens }\end{array}$ & $\%$ & $\begin{array}{c}\mathrm{Nr} \text { of collected } \\
\text { specimens }\end{array}$ & $\%$ & $\begin{array}{l}\mathrm{Nr} \text { of collected } \\
\text { specimens }\end{array}$ & $\%$ & $\begin{array}{l}\mathrm{Nr} \text { of collected } \\
\text { specimens }\end{array}$ & $\%$ \\
\hline Hydropsychidae & 1681 & 58.65 & 3679 & 79.15 & 6410 & 74.19 & 6939 & 57.28 \\
\hline Chironoidae & 934 & 32.59 & 643 & 13.83 & 1708 & 19.27 & 4583 & 37.83 \\
\hline Bactdae & 126 & 4.40 & 242 & 5.21 & 270 & 3.13 & 388 & 3.20 \\
\hline Blefariceridae & 8 & 0.28 & 34 & 0.73 & 59 & 0.68 & 110 & 0.91 \\
\hline Simuliidae & 116 & 4.05 & 30 & 0.65 & 191 & 2.21 & 46 & 0.38 \\
\hline Megapodagrionidae & 1 & 0.03 & 20 & 0.43 & 2 & 0.02 & 48 & 0.40 \\
\hline Total & 2866 & 100.00 & 4648 & 100.00 & 8640 & 100.00 & 12113 & 100.00 \\
\hline
\end{tabular}


Simuliidae were the least abundant (46 specimens, $0.38 \%$ ).

A comparison between the abundance means of $S$. pertinax in sections $\mathrm{CC}$ and TC revealed a sharp drop in the abundance ratio $(88.16 \% ; t=6.56 \mathrm{P}<0.05)$, about the same which occurred in the ratio of CS to TS $(97.4 \% ; t=$ $1.65 \mathrm{P}>0.05)$. However, only the ratio $\mathrm{CC}$ to $\mathrm{TC}$ was statistically significant (Table IV).

A considerable reduction in the abundance ratio $\mathrm{CC}$ to TC $(75.91 \%)$ in family Simuliidae was observed, but it was not statistically significant $(t=1.83 \mathrm{P}>0.05)$. In connection with sections CS and TS, given the resulting ratio, no statistical test was necessary.

No reduction in abundance was observed concerning the families Chironomidae, Bactidae, Blephariceridae, Megapodagrionidae and Hydropsychidae (Table IV) in treated and control sections.

\section{DISCUSSION}

The climatic conditions observed in the region under study, as well as the physicochemical variables measured at the sampling sites of the Muricana and Pedra Branca rivers, were within the limits of those observed by AraújoCoutinho et al. (1999) in the same region. This means that, concerning abiotic factors, the period chosen for the study was by no means atypical.

A further physicochemical peculiarity of both rivers stands out from the rest: no statistically significant differences were detected when control and treated section means were compared. Characterized as a single exception to this assertion, the variable depth in slow water sampling sites was different in each river. However, taking into account the low representativeness of the fauna in those sites, such occurrence does not invalidate the assumption that physicochemical factors did not affect the mean abundance of the local fauna. It can thus be inferred that larvicides were the only factors not common to both control and treated sections.

Associated entomofauna samples, collected from both rivers, showed a remarkable similarity to each other and to those from the same region described by AraújoCoutinho et al. (1999) and by Dellome-Filho (1986) in the state of Paraná, in connection with $S$. incrustatum. However, in spite of such a close similarity, prevalence data differed. These authors pointed out that the family Chironomidae was predominant, but the present investigation revealed a predominance of the family Hydroprychidae.

The marked reduction in the number of $S$. pertinax specimens found in the treated section of Muricana river occurred as expected. Since the 1970's temephos has been widely recommended for controlling simuliid populations (Back \& Hamper 1979) and, more specifically, for controlling $S$. pertinax populations in coastal São Paulo (Sucen 1977). This confirms the efficacy of temephos in suppressing simuliids in regions where the target population has not developed resistance to it.

The rather marked reduction in the percentage of $S$. pertinax populations in slow water was not, however, statistically significant. This may be due to the inconsistent seasonal distribution observed in this region as, characteristically, this species is not well adapted to such environments (Araújo-Coutinho et al. 1999).

On account of the absence of homogeneous seasonal distribution in the family Simuliidae, no conclusion could

TABLE IV

Larval abundance of Simulium pertinax populations and associated entomofauna under treatment with Bti and temephos, during 1995 to 1997, in rivers Muricana and Pedra Branca, Paraty, state of Rio de Janeiro, Brazil

\begin{tabular}{|c|c|c|c|c|c|c|c|c|}
\hline $\begin{array}{l}\text { Observation } \\
\text { points for } \\
\text { section }\end{array}$ & $\begin{array}{r}\text { Control } \\
\text { of } \mathrm{Mu}\end{array}$ & $\begin{array}{l}\text { ction } \\
\text { ana }\end{array}$ & $\begin{array}{l}\text { Treate } \\
\text { of } \mathrm{M}\end{array}$ & $\begin{array}{l}\text { tion } \\
\text { ana }\end{array}$ & $\begin{array}{l}\text { Contrc } \\
\text { of Ped }\end{array}$ & $\begin{array}{l}\text { ction } \\
\text { ranca }\end{array}$ & $\begin{array}{l}\text { Trea } \\
\text { of } \mathrm{Pe}\end{array}$ & $\begin{array}{l}\text { section } \\
\text { Branca }\end{array}$ \\
\hline & Point & Point & Point & Point & Point & Point & Point & Point \\
\hline Fauna & $\mathrm{CC}$ & $\mathrm{CS}$ & $\mathrm{TC}$ & $\mathrm{TS}$ & $\mathrm{CC}$ & $\mathrm{CS}$ & $\mathrm{TC}$ & $\mathrm{TS}$ \\
\hline Simulium pertinax & $\begin{array}{c}665.01 \\
\mathrm{~s}=563.02\end{array}$ & $\begin{array}{c}1.04 \\
\mathrm{~s}=3.87\end{array}$ & $\begin{array}{c}93.12 \\
\mathrm{~s}=133.54\end{array}$ & $\begin{array}{c}0.20 \\
\mathrm{~s}=0.76\end{array}$ & $\begin{array}{c}805.85 \\
s=503.69\end{array}$ & $\begin{array}{c}14.98 \\
\mathrm{~s}=42.46\end{array}$ & $\begin{array}{c}95.44 \\
\mathrm{~s}=127.80\end{array}$ & $\begin{array}{c}0.39 \\
\mathrm{~s}=1.51\end{array}$ \\
\hline Simuliidae & $\begin{array}{c}11.30 \\
s=20.69\end{array}$ & $\begin{array}{c}0.15 \\
\mathrm{~s}=0.51\end{array}$ & $\begin{array}{c}2.80 \\
\mathrm{~s}=5.84\end{array}$ & $\begin{array}{c}0.13 \\
\mathrm{~s}=0.47\end{array}$ & $\begin{array}{c}18.72 \\
\mathrm{~s}=35.91\end{array}$ & $\begin{array}{c}0.30 \\
\mathrm{~s}=1.46\end{array}$ & $\begin{array}{c}4.51 \\
\mathrm{~s}=9.75\end{array}$ & 0.00 \\
\hline Chiromomidae & $\begin{array}{c}91.35 \\
\mathrm{~s}=101.32\end{array}$ & $\begin{array}{c}1.24 \\
\mathrm{~s}=3.78\end{array}$ & $\begin{array}{c}63.13 \\
\mathrm{~s}=69.06\end{array}$ & $\begin{array}{c}0.53 \\
\mathrm{~s}=1.45\end{array}$ & $\begin{array}{c}164.87 \\
\mathrm{~s}=145.80\end{array}$ & $\begin{array}{c}4.53 \\
\mathrm{~s}=7.98\end{array}$ & $\begin{array}{c}445.88 \\
\mathrm{~s}=227.48\end{array}$ & $\begin{array}{c}8.79 \\
\mathrm{~s}=15.97\end{array}$ \\
\hline Bactidae & $\begin{array}{c}12.38 \\
\mathrm{~s}=16.68\end{array}$ & $\begin{array}{c}0.05 \\
\mathrm{~s}=0.24\end{array}$ & $\begin{array}{c}23.76 \\
\mathrm{~s}=48.46\end{array}$ & $\begin{array}{c}0.15 \\
\mathrm{~s}=0.73\end{array}$ & $\begin{array}{c}26.29 \\
\mathrm{~s}=27.68\end{array}$ & $\begin{array}{c}0.45 \\
\mathrm{~s}=1.60\end{array}$ & $\begin{array}{c}35.54 \\
\mathrm{~s}=27.68\end{array}$ & $\begin{array}{c}2.93 \\
\mathrm{~s}=12.40\end{array}$ \\
\hline Blephariceridae & $\begin{array}{c}0.77 \\
\mathrm{~s}=1.36\end{array}$ & 0.00 & $\begin{array}{c}1.90 \\
\mathrm{~s}=4.52\end{array}$ & $\begin{array}{c}1.34 \\
\mathrm{~s}=5.85\end{array}$ & $\begin{array}{c}5.89 \\
\mathrm{~s}=5.01\end{array}$ & 0.00 & $\begin{array}{c}10.66 \\
\mathrm{~s}=12.87\end{array}$ & $\begin{array}{c}0.31 \\
\mathrm{~s}=1.11\end{array}$ \\
\hline Megapodagrionidae & $\begin{array}{c}0.10 \\
\mathrm{~s}=0.34\end{array}$ & 0.00 & $\begin{array}{c}1.86 \\
\mathrm{~s}=8.37\end{array}$ & $\begin{array}{c}0.05 \\
\mathrm{~s}=0.24\end{array}$ & $\begin{array}{c}0.13 \\
\mathrm{~s}=0.51\end{array}$ & 0.00 & $\begin{array}{c}1.14 \\
\mathrm{~s}=3.64\end{array}$ & $\begin{array}{c}3.59 \\
\mathrm{~s}=9.55\end{array}$ \\
\hline Hydropsychidae & $\begin{array}{c}98.19 \\
\mathrm{~s}=42.87\end{array}$ & $\begin{array}{c}68.52 \\
\mathrm{~s}=33.78\end{array}$ & $\begin{array}{c}187.35 \\
s=60.90\end{array}$ & $\begin{array}{c}177.55 \\
\mathrm{~s}=54.23\end{array}$ & $\begin{array}{c}300.81 \\
\mathrm{~s}=179.59\end{array}$ & $\begin{array}{c}335.16 \\
\mathrm{~s}=121.34\end{array}$ & $\begin{array}{c}311.81 \\
\mathrm{~s}=125.14\end{array}$ & $\begin{array}{c}376.48 \\
s=133.62\end{array}$ \\
\hline
\end{tabular}

CC: control cascade; $\mathrm{CS}$ : control still; TC: treated cascade; TS: treated still 
be drawn about the effect of temephos on it. Nevertheless, it can be inferred that this larvicide had actually a role in the reduction observed, for temephos is recognizsably an alternative means of controlling populations of this family.

It may not be possible to attribute the observed $30.9 \%$ reduction in number of Chironomidae population to the action of temephos, as a cause-effect relation, owing to the fact that the variation from the expected values was not statistically significant. On the other hand, it would be unwise to reject the hypothesis of some action of the larvicide, as the non-significance may be attributed to changes in abundance observed in the course of this study.

A substantial number of reports on the high susceptibility of the family Chironomidae to temephos gives added weight to such considerations, which apply to species adapted to lentic (Wallace et al. 1973, Mulla et al. 1975, Ali \& Mulla 1976) as well as to lotic (Dejoux 1977, Wallace \& Hynes 1981) environments.

Contrary to the studies of Quellenec (1970), Wallace and Hynes (1981) and Wallace et al. (1973), demonstrating the action of temephos on immature Ephemeroptera and Trichoptera, it can be said that the fauna composed of families Bactidae and Hydropsychidae was not affected by temephos at the concentrations currently used: no reduction was observed in the mean abundance of either one of the families.

Low representativeness and seasonal distribution of abundance are obstacles to any analysis of the impact of temephos on the families Blephariceridae and Megapodagrionidae.

During a study in the same region, Araújo-Coutinho et al. (1999) had already observed irregular distribution and low abundance of these families. It can be thus inferred that such families are the least representative of the entomofauna associated to $S$. pertinax. Further research, chiefly on Megapodagrionidae, is recommended as, taking into account the studies of Gorayeb and Pinger (1978), members of this family were observed to prey on Simulium larvae and de Moore and Breeland (1967) demonstrated the susceptibility of the order Odonata to temephos.

The high susceptibility of $S$. pertinax to Bti at the concentration applied during the present evaluation had already been expected, as this is the chief control agent in use for abatement of simuliid populations in areas where the target is mainly represented by S. pertinax (AraújoCoutinho 1995b).

Concerning the statistical non-significance in the reduction observed in the simuliid abundance, this may be related to both their low occurence during the course of the study. It would not be advisable to think of such a statistical inference as absolutely reliable, taking into consideration the results of several studies which testify to the high susceptibility of many species of Simuliidae to larvicides with Bti base, such as $S$. verecundum (Undeen \& Colbo 1980) and S. damnosum (Lacey et al. 1982).

Reports in the literature on the effect of Bti on Chironomidae larvae in lotic environments are quite conflicting, as attest the studies by Lacey et al. (1982), in the
Ivory Coast and Merrit et al. (1989) in the United States of America. The latter did not observe any reduction in the Chironomidae population after using a Bti concentration of $1.6 \mathrm{ppm}$ applied during $10 \mathrm{~min}$. On the other hand, Dejoux et al. (1985), in the Ivory Coast, de Moor et al. (1986), in South Africa, and Molloy (1992) in the United States, reported a population reduction by using the same concentration of Bti. Regarding the species adapted to lentic environments, field and laboratory experiments have demonstrated the high susceptibility of certain chironomid species to Bti formulations (Rodcharoen et al. 1991, Kondo et al. 1992, Charbonneau et al. 1994). However, the results of the present investigation attest that the members of the family Chironomidae found on the slopes of Serra do Mar were not affected by the Bti concentrations used in this study.

The results observed concerning the family Chironomidae apply to Hydropsychidae. Undeen and Colbo (1980), studying the efficacy of Bti against $S$. verecundum in Canada, did not observe any effect on the order Trichoptera. Similar results were reported by Merrit et al. (1989), concerning specifically the family Hydropsichidae. On the other hand, Dejoux et al. (1985), and de Moor et al. (1986), working in the African continent, reported an effect of Bti on these insects. It is possible that the effects were due formulation components rather than toxins of the bacterium.

Our results concerning the family Hydropsychidae, based on mean abundance, did not reveal any susceptibility of this population to Bti. Further study on this family is justified as, in addition to being the most prevalent of the associated entomofauna with S. pertinax, this family preys on simuliid larvae (Gorayeb \& Pinger 1978).

The results of studies on Bactidae unanimously agree about the lack of susceptibility of this family to Bti (Undeen \& Colbo 1980, Colbo \& Undeen 1980, Merritt et al. 1989, 1991). The present study arrived at similar results: no reduction was observed in the mean abundance in the treated section.

Reports on the family Blephariceridae were not found in the literature. With regard to its susceptibility to Bti, the results do not indicate any efficacy against such Diptera.

As observed in connection with the effect of temephos on non-target entomofauna, the family Megapodagrionidae from the river treated with Bti did not present enough prevalence nor seasonal abundance to allow analysis.

It can be stated that both larvicides used in this investigation gave similar results without negative environment impact, although they have active ingredients and modes of action that are completely different.

\section{ACKNOWLEDGEMENTS}

To Dr Clara FG Cavados, Laboratory of Bacterial Physiology, Department of Bacteriology, Instituto Oswaldo CruzFiocruz, for her technical advice in Microbiology and revision of the manuscript; Dr Lawrence A Lacey for the revision of the manuscript; staff of the Laboratory for Simuliid Investigation, Superintendência de Controle de Endemias, for their collaboration in screening and identification of entomofauna and invaluable support during the field work. 


\section{REFERENCES}

Ali A, Mulla MS 1976. Insecticidal control of chironomid midges in the Santa Ana river water spreading system, Orange County, California. J Econ Entomol 69: 509-513.

Anderson JR, Dicke RJ 1960. Ecology of the immature stages of some Wisconsin black flies (Simuliidae: Diptera). An Entomol Soc Am 53: 386-404.

Andrade CFS, Castelo Branco Jr A 1990. Methods for field detection of resistence to temephos in simuliids. Larval esterase level and topical application of insecticide to adults. Mem Inst Oswaldo Cruz 85: 291-297.

Araújo-Coutinho CJPC 1995a. Biological control program against simuliids in the state of São Paulo. Mem Inst Oswaldo Cruz 90: 131-133.

Araújo-Coutinho CJPC 1995b. Controle de vetores no estado de São Paulo com utilização de Bacillus thuringiensis var. israelensis. Rev Soc Entomol do Brasil, Ciclo de Palestras sobre Controle Biológico de Pragas, p. 203.

Araújo-Coutinho CJPC, Lacey LA 1990. Controle de simulídeos com concentrado emulsionável de Bacillus thuringiensis. Bol Of Sanit Panam 108: 213-219.

Araújo-Coutinho CJPC, Maia-Herzog M, Souza BC 1988. Levantamento das espécies do gênero Simulium Latreille (Diptera: Simuliidae) no litoral norte do estado de São Paulo. Revta Bras Ent 32: 11-17.

Araújo-Coutinho CJPC, Mello RP, Freire NMS 1999. The seasonal abundance of Simulim (Chirostilbia) pertinax, Kollar 1832, (Diptera, Simuliidae) and related entomological fauna in the municipality of Paraty, RJ, Brasil. Rev Univ Rural, Sér Ci da Vida 21: 107-116.

Back C, Hamper PP 1979. Succession saisonniére, emergenge, voltinisme et répartition de mouches noires de Laurentides (Diptera: Simuliidae). Can J Zool 57: 627-639.

Charbonneau CS, Drobney RD, Raben CF 1994. Effects of Bacillus thuringiensis var. israelensis on nontarget benthic organisms in a lentic habitat and factors affecting the effecting the efficacy of the larvicide. Envir Toxic Chemis 13: 267-279.

Colbo MH, Undeen AH 1980. Effect of Bacillus thuringiensis var. israelensis on non-target insects in stream trials for control of Simuliidae. Mosq News 40: 368-376.

Dejoux C 1977. Action de l'Abate sur les invertébrés aquátiques. III. Effects de premiers traitement da la Bagone, ORSTOM, Bouaké Rap, 14 pp.

Dejoux C, Gibon FM, Yameago L 1985. Toxité pour la fauna non-cible de quelques insecticides nouveaux en mileu aquitique tropical. IV. Bacillus thuringiensis var. israelensis H-14. Rev Hydrobiol Trop 18: 31-49.

Dellome-Filho J 1986. Simuliofauna do Rio Marambi, Morretes, Paraná, PhD Thesis, Universidade Federal do Paraná, Curitiba, 126 pp.

Gorayeb IS, Pinger RR 1978. Detecção de predadores naturais das larvas de Simulium fulvinotum Cerqueira e Mello, 1968 (Diptera: Nematocera). Acta Amazonica 8: 629-637.

Kondo S, Ohba M, Ishii T 1992. Larvicidal activity of Bacillus thuringiensis against nuisance chironomid midges (Diptera: Chironomidae) of Japan. Lett Appl Microb 15: 207-209.

Kurtak D, Jamnback H, Meyer R, Ocran M, Renaud P 1987. Evaluation of larvicides for the control of Simulium damnosum (Diptera:Simuliidae) in West Africa. J Amer Mosq Control Assoc 3: 201-210.
Lacey LA, Escaffre H, Philippon B, Sékétéli A, Guillet P 1982. Large river treatment with Bacillus thuringiensis for the control of Simulium damnosum s. 1. in the Onchocerciasis Control Programme. Tropenmed Parasitol 33: 97-101.

Lewis DJ, Bennett GF 1974. An artificial substrate for the quantitative comparison of the densities of larval simuliid (Diptera) populations. Can J Zool 52: 773-775.

Maia-Herzog M, Felippe-Bauer ML, Malaguti R, CarvalhoLeite TC 1988. A contribution to the study of Simulium and culicoides of Rio de Janeiro: monthly incidence and biting activity. Mem Inst Oswaldo Cruz 83: 95-99.

Merritt RW, Walker ED, Wilzbach MA, Cummins KW, Morgan WT 1989. A broad evaluation of B.t.i. for black fly (Diptera: Simuliidae) control in a Michigan River: efficacy, carry and non-target effects on invertebrates and fish. $J$ Amer Mosq Cont Assoc 5: 397-415.

Merritt RW, Wipfli MS, Wotton RS 1991. Changes in feeding habits of selected nontarget aquatic insects in response to live and Bacillus thuringiensis var. israelensis de Barjackilled blackfly larvae (Diptera: Simuliidae). Can Entomol 123: 179-185.

Molloy D 1992. Impact of the black fly (Diptera: Simuliidae) control agent Bacillus thuringiensis var. israelensis on chironomids (Diptera: Chironomidae) and other nontarget insects: results of ten field trials. J Amer Mosq Cont Assoc 8: 24-31.

de Moor FC, Chutter FM, Moor IJ 1986. Drift behavior and microhabitat selection in the preimaginal stages of Simulium chutteri (Diptera,Simuliidae). Hydrobiologia 133: 143-154.

de Moore JB, Breeland S G 1967. Field evaluation of two mosquito larvicides, Abate and Durban, against Anopheles quadrimaculatus and associated Culex species. Mosq News 27: 105-111.

Mulla MS, Barnad DR, Norland RL 1975. Chironomid midgesand their control in Spring Valley Lake, California. Mosq News 35: 389-395.

Quélennec G 1970. Essais sur le terrain de nouvelles formulations d'insecticides, OMS-187, OMS-786 OMS-971, contre les larves de simulies. Bull WHO 43: 617-620.

Rodcharoen J, Mulla MS, Chaney JD 1991. Microbial larvicides for the control of nuisance aquatic midges (Diptera: Chironomidae) inhabiting mesocosms and man-made lakes in California. J Amer Mosq Cont Assoc 7: 56-62.

Ruas Neto ALR 1984. Bacillus thuringiensis var. israelensis como alternativa no controle de simulídeos no Rio Grande do Sul. I. Susceptibilidade a campo. B Saúde 11: 21-26.

Sucen-Superintendência de Controle de Endemias 1977. Relatório das atividades do programa de controle de simulídeos, $67 \mathrm{pp}$.

Undeen AH, Colbo MH 1980. The efficacy of Bacillus thuringiensis var. israelensis against blackfly larvae (Diptera: Simuliidae) in their natural habitat. Mosq News 40: 181-184.

Wallace RR, Hynes HBN 1981. The effect of chemical treatment against blackfly larvae on the running waters. In $\mathrm{M}$ Laird, Blackfly, Academic Press, London, p. 237-258.

Wallace RR, West A S, Downe A E R, Hynes HBN 1973. The effects of experimental blackfly (Diptera: Simuliidae) larviciding with ABATE, DURBAN and methoxychlor on streams invertebrates. Can Ent 105: 817-833. 